\title{
Man of the Theatre: Stage Performances of T. S. Eliot's Work in Spain (1949-2016)
}

\author{
Dídac Llorens-Cubedo ${ }^{1}$ []
}

Accepted: 1 August 2021 / Published online: 11 September 2021

(C) The Author(s) 2021

\begin{abstract}
T. S. Eliot's presence in Spanish theatres has taken various forms. His verse drama enjoyed a relative popularity in the late 1940s and in the 1950s: Murder in the Cathedral, The Family Reunion and The Cocktail Party were staged by student and amateur groups, "chamber" companies and even a national theatre. Reviews were ambivalent, most of them finding fault with the plays' poetic density as an impediment for performance. Although, as a conservative Anglo-Catholic, Eliot was a priori an unproblematic author for the Francoist establishment and its censorship, critics loyal to Spanish National Catholicism were uncomfortable with the tragic fatalism of The Family Reunion, or with the non-judgemental treatment of adultery in The Cocktail Party. When Eliot's plays were losing their appeal from the late 1950s onwards, only Murder in the Cathedral was occasionally performed in Spain. More recently, intermedial transpositions and dramatizations of Eliot's poetry have consolidated his image as a great influential poet whose drama is a rarity.
\end{abstract}

Keywords T. S. Eliot $\cdot$ Drama $\cdot$ Stage productions $\cdot$ Dramatised poetry $\cdot$ Reception $\cdot$ Spain

\section{“Drama Is My Passion” (Introduction)}

April 1951 was for T. S. Eliot the month of a holiday spent in Malaga, Seville and Granada, having travelled to Spain to rest and convalesce. In an interview, he seemed eager to emphasise a current devotion to drama: "At present [...] I am a man of the theatre, and drama is my passion" (Calvo, 1951, p. 3). ${ }^{1}$ Although not mentioned in this interview, we may assume that Eliot took advantage of the days spent

\footnotetext{
1 "Ahora [...] soy hombre de teatro, y el teatro es lo que más me apasiona". All translations are by the author.
}

Dídac Llorens-Cubedo

dllorens@flog.uned.es

1 Universidad Nacional de Educación a Distancia (UNED), Madrid, Spain 
in Madrid during early May to supervise arrangements for the production of The Cocktail Party (1949) at the Teatro María Guerrero, scheduled a few months later.

The Cocktail Party had run successfully in London for two years. This success was the peak of Eliot's career as a playwright: finally, he could reach a wide audience by dramatizing spiritual conflict through the medium of comedy, in verse and in a modern setting. From the 1940s onwards, Eliot wrote primarily for the stage, but theatre had always fascinated him: emblematic essays from the 1920s ("Hamlet," "Philip Massinger" or "The Possibility of a Poetic Drama") discuss the achievement of Elizabethan dramatists or the renewal of contemporary drama through poetry. Some of his best known early poems rely on devices that could be considered dramatic: characterisation by means of monologue in "The Love Song of J. Alfred Prufrock" or "Gerontion," scenes as structural units in "Portrait of a Lady," or the succession of voices and situations in The Waste Land. Further, the unfinished verse play Sweeney Agonistes (1932) was an integral part of the canonical Collected Poems since its first 1936 edition.

Eliot alternated the composition of Four Quartets (1936-1942), his valedictory to meditative poetry, with that of the plays Murder in the Cathedral (1935) and The Family Reunion (1939). After the completion of the Quartets, their author was determined "to use the forms of popular drama to bring his religious ideas to a larger and more secular audience than his poems were likely to attract" (Smith, 2014, p. 251). He achieved this with The Cocktail Party and, to a lesser extent, with The Confidential Clerk (1953) and The Elder Statesman (1958), which were more coldly received.

Eliot had hoped that a new generation of playwrights would consolidate his endeavour to reinstate poetic drama, but theatre in Britain took a very different turn: "The 'kitchen sink drama' of the late 1950s famously swept all before it, leaving Eliot and his fellow verse dramatists stranded in its wake, remnants of British theater's bad old days" (Chinitz, 2003, p. 151). As Perloff has argued, "from the 1960s well into the 90s, Modernism was a term of opprobrium," and Eliot was disparaged as elitist and reactionary (2007, pp. 14-5). In this unfavourable context, commercial productions of his plays became increasingly rare.

The success and decline of Eliot's drama in Britain had its reflection-notwithstanding circumstances of political and cultural isolation-in Spain, where it was mostly performed during the 1950s. The earliest Spanish performances are contemporary with the concession of the Nobel Prize to Eliot in 1948, and the international recognition and popularity that came with it. Unlike other British intellectuals, Eliot had made no pronouncement against Franco's uprising or the aftermath of the Spanish Civil War (Ackroyd, 1984, p. 243). As a neutral, eminently religious poet and dramatist, he was in principle unproblematic for the Francoist regime and its censors: "a Catholic poet in line with the ultra-orthodox religious and political beliefs enforced in Spain. Political authorities [...] did not consider Eliot a dangerous, corruptive influence" (Rodríguez Guerrero-Strachan, 2007, p. 148).

Spanish critics, however, did point out differences in Eliot's moral, religious and cultural stance, as we will see. These prevented the popularity of his drama in Spain, as did its textual depth and Eliot's status as a paragon of intellectual poetry. Nonetheless, Eliot's most successful plays, as well as a number of dramatizations or dramatic transpositions of his poetry, have been staged in Spain (a comprehensive list, 
from 1949 to 2016, is provided as an Appendix ${ }^{2}$ ). The sections that follow explore their nature, history and reception, showing that Eliot's fame as a dramatist was limited-by such factors as those just mentioned-and short-lived, and that his presence on the Spanish stage in more recent decades has been as a poet and cultural referent rather than a playwright.

\section{A Great Poet and the Poetry in His Plays}

Eliot wrote his last three plays (The Cocktail Party, The Confidential Clerk and The Elder Statesman), his comedies, with the conviction that theatre should appeal to a large audience and, in so doing, fulfil a social function (Gardner, 1985, pp. 43-44). On the basis of Eliot's aspiration to make his plays genuinely popular, these have been set against the intellectual avant-garde poetry for which he is famed and from which, as a playwright, he wished to distance himself (Chinitz, 2003, p. 129). Judging by the Spanish press of the 1940s and 1950s, Eliot's dissociative project was not entirely successful.

The short news item that announced the 1952 première of The Cocktail Party at the Teatro María Guerrero in Madrid mentioned Eliot's dramatic writing as part of a profile of the author: "T. S. Eliot, who has, because of his ascendancy as a multifaceted author-professor, editor of avant-garde journals, essayist, novelist, critic, poet, playwright and philosopher-the universal status of a pioneer" (De Castro, 1952, p. 10). ${ }^{3}$ This characterisation, somewhat erroneous in its hyperbole, portrays Eliot as a versatile, prolific and influential man of letters, rather than as a man of the theatre.

This vision of the author is coherent with an emphasis on the literariness of his plays. When asked about the appeal of The Cocktail Party, the translator of the play as staged in Madrid in 1952, José Méndez Herrera, alluded to Eliot as a Nobel Laureate who had authored "a comedy of great literary qualities" (Laborda, 1952, p. 6). ${ }^{4}$ Four years later, a production of The Family Reunion by Dido Pequeño Teatro led a reviewer to highlight lyrical and mystical aspects of a play that should be read as well as seen, in order to apprehend its complex meaning (Marqueríe, 1956, p. 59). It is suggested, therefore, that Eliot's plays have the status of literary texts and that there is more to them than performance can convey.

The view that the text has a special relevance in Eliot's drama, which can be interpreted both as praise and criticism, is reflected in more specific comments on the language used, the density of its content and its poetic quality. The report of a

\footnotetext{
${ }^{2}$ Each entry includes as many basic data as has been possible to retrieve from reviews and secondary sources, as well as the following databases and catalogues: Centro de Documentación de las Artes Escénicas y de la Música, Teatro Español Contemporáneo (Fundación Juan March) and Escena Digital (Museu de les Arts Escèniques). A more detailed version of this list is available on the TEATREL-SP website ("Stage Performances in Spain"): http://teatrel.linhd.uned.es/paginas/teatrel-inspanish-stage. html.

3 “T. S. Eliot, que tiene, por su jerarquía de polígrafo-catedrático, editor de revistas de vanguardia, ensayista, novelista, crítico, poeta, dramaturgo y filósofo -, el valor universal de precursor".

4 "[U]na comedia de grandes calidades [sic] literarias".
} 
performance of Murder in the Cathedral at the atrium of Burgos Cathedral in 1950 refers to Eliot's "lenguaje conceptuoso" and to alleged Shakespearean echoes in the choruses (Haro Tecglen, 1950, n.p.). A reviewer of Dido's The Family Reunion defined the play's syntactic compactness as "that 'nocturne' of his syntaxentwined, arranged" (Jenabe, 1956, p. 6), while another made an interesting distinction between the admirable lyrical choruses and the dialogue, criticised as "slow, obscure and uninteresting, becoming almost an anti-dialogue" (Fernández Asís, 1956 b, p. 7). ${ }^{5}$ What is meant by "anti-dialogue" is precisely poetic soliloquy, at odds with conventional plot-based drama.

In his essay "Poetry and Drama" (1950), Eliot acknowledged this flaw and explained how he attempted to avoid it in The Cocktail Party: "I laid down for myself the ascetic rule to avoid poetry which could not stand the test of strict dramatic utility" (Eliot, 2018, p. 601). Yet, the 1952 production of The Cocktail Party in Madrid also invited comment on its "poetry" as an impediment for the development of events: "This poetic and famous comedy has an external structure of minimal incident. The central anecdote is brief and lacking the material support that would maintain the spectator's interest in the action, which is practically nonexistent" (García Espina, 1952, p. 2). ${ }^{6}$ Dramatic action is obscured by poetic language, precise and weighty. This quality of Eliot's verse drama is demanding for an audience, as noted by a Spanish critic after the première of The Family Reunion in Madrid: "This is why it becomes so hard to listen to. When we grasp a sentence, we have missed several others. This usury of language, therefore, has its limitations, especially on stage" (Jenabe, 1956, p. 6). ${ }^{7}$

The adjectives and categories used to describe The Family Reunion and The Cocktail Party, in Spanish reviews of the late 1940s and the 1950s, summarise the critics' perception of them as poetic in their expression, profound in their thematic range, but limited in performance because of those features: they are "symbolic and poetic" (Laborda, 1952, p. 5), "philosophical and theological" (Corifeo, 1952, p. 6), but "experimental" (Marqueríe, 1956, p. 59), examples of "theatre of ideas" (De Cala, 1949, p. 6) or "minority” drama (De Alcalá, 1952, p. 17).

These descriptive labels explain why Eliot's plays have seldom been produced commercially in Spain. During the two decades following the Spanish Civil War, when Eliot's drama could have been more popular, the nation was constrained by a severe recession and a repressive autocracy_although, as suggested above, its iron-fisted censorship was unlikely to target Eliot. In these years, urban commercial theatres would typically offer variety shows, naïve comedies, farce, vaudeville, melodrama or Spanish Golden Age drama (Ascunce Arrieta, 2015, pp. 386-87). In

\footnotetext{
5 “[E]se 'nocturno' de su sintaxis, trabada, organizada"; "lento, oscuro y poco interesante por orientarse hacia un antidiálogo".

6 "La poética y famosa comedia tiene un desenvolvimiento exterior de incidentes mínimos. El punto anecdótico es breve. No hay en él ningún gancho material donde sujetar un poco el interés de una acción que prácticamente no existe".

7 "Por eso resulta tan trabajoso de oír. Cuando penetramos una frase, se nos han escapado varias. Tiene, pues, su límite—sobre todo en el escenario-esta usura del idioma".
} 
this context, programming plays by Eliot was a financial hazard, and consequently exceptional.

\section{Commercial, "Chamber" and Amateur Productions}

The production of The Cocktail Party at the Teatro María Guerrero in Madrid, as part of the 1951-52 season, was viable because programmed by a state theatre receiving public funding. From the relative security of a teatro nacional, Luis Escobar and Huberto Pérez de la Ossa — who had managed the theatre since 1940 and directed Eliot's play in 1952 - could take the risk of introducing international playwrights to theatre-goers in Madrid. Escobar declared that The Cocktail Party was the most challenging play that he had ever produced: it was initially scheduled for 1951 but had to be postponed to the following season (INAEM, 2017). The actors also stressed the difficulty of expressing naturalistically the play's depth of meaning (Corifeo, 1952, p. 6).

Despite his ample experience as a poet, playwright and translator of English and American literature, Méndez Herrera produced a prose version of The Cocktail Party. A critic regretted this and expressed his curiosity to hear poetry applied to contemporary scenes of everyday life (Marqueríe, 1952, p. 9)—in giving such an exact definition of Eliot's method since The Family Reunion, he was hitting the nail on the head. As we saw in the preceding section, both Escobar and De la Ossa's production and Méndez Herrera's version were received with ambivalence: the quality of Eliot's text was praised, while pointing out that the play had failed to connect with its audience.

The Family Reunion, as produced in Madrid in 1956, had a comparable reception. It was, however, a very different production by "Dido Pequeño Teatro," the most prestigious and established of the "chamber theatre" companies operating in the years of Franco's dictatorship (Bloin, 2007, p. 110). Government censorship restricted chamber productions to a sole performance, which led to comparative leniency. This practice, together with the absence of commercial pressure, allowed these teatros de cámara or de arte y ensayo to be more daring in their choice of repertoire. Dido's artistic director, Josefina Sánchez Pedreño, conceived of the company's task as educational and pioneering: they aspired to make international and avant-garde drama available to the younger generation (qtd. in Bloin, 2007, p. 107) and were the first to produce plays by Beckett and Ionesco in Spain (Hormigón, 2005, p. 733).

Like most companies of its kind, Dido had limited resources: a reviewer of their Reunión de familia commented on the poor technical conditions of the assembly room of the Social Security central office (Prego, 1956, p. 9), the unusual space where the play was staged. Dido faced financial and practical difficulties, but often counted on first-rate writers and performers for their productions: two women associated with the Generación del 27, the actress and poet Josefina de la Torre and the prolific author Carmen Conde, were involved in their production of Reunión de familia. De la Torre played Agatha-the central female character, a spiritual guide for the protagonist - and Conde adapted Elizabeth Gate's prose translation to Eliot's model of dramatic verse. 
In a short text included in the programme, Conde metaphorically alludes to the underlying but flowing rhythm that the words sustain: "There is a deep river flowing through them; it can barely be heard, but it is there" (Sanchez Pedreño, 1956, original emphasis). ${ }^{8}$ In presenting the play before the première, she salutes Eliot's use of verse as inaugurating a promising trend in international drama; in her adaptation, she has attempted to echo the rhythm in the original, whose characteristics and effect she describes: "the author's poetic language resorts to intimately rhythmic, extended periods, mysteriously chained, gradually enveloping the audience with their mystic fascination" (Conde, 1956, p. 8). ${ }^{9}$ Conde's version, rendered in "admirable unrhymed verse" (Marqueríe, 1956, p. 59), fittingly gave the performance "an air of liturgical procession with the rhythm of a psalm" (Jenabe, 1956, p. 6). ${ }^{10}$ Indeed, Eliot's dramatic poetry has been connected, as a possible influence, with Conde's own practice as a dramatist (Morales, 1995, p. 11).

The two Eliot productions discussed so far in this section aroused the interest of the press, being the most ambitious and professional. Murder in the Cathedral, soon canonised as a modern classic, has also had-as in other countries-a wider popularity in Spain. Performances, however, have often been amateur. The historical and spatial settings of the play determined its first performance at Canterbury Cathedral, and those that followed elsewhere. The "Plaça del Rei" in the vicinity of Barcelona Cathedral (1948) or its "Pla de la Seu" (2012), the "Puerta de la Pellejería" of Burgos Cathedral (1950) or the "Seu d'Ègara" in the Catalan town of Terrassa (1950) served as medieval backdrops for Asesinato en la Catedral. Interestingly, these settings have connections with the plot and characters of the play: Henry II's daughter, Elinor of England and Queen of Castile, is buried in Burgos; a fresco in one of the Romanesque churches of the "Seu d'Ègara" depicts the martyrdom of Beckett and one of the chapels of Barcelona Cathedral is dedicated to the saint. More recently (2016), a version of Eliot's play titled La sangre de los mártires (The Blood of the Martyrs) was performed at the Mosque-Cathedral of Cordova.

As exemplified above, Murder in the Cathedral has been attractive for cultural or religious associations and, up to the 1970s, student performing groups. The students of the Institut del Teatre in Barcelona produced it twice, in 1948 and in 1963. The 1948 production, mentioned above, was commissioned by Catholic Action for its Diocesan Conference in Barcelona. In the Institut's annual report, it is described as the most important event of the academic year 1948-49, during which Ashley Dukes, who had produced Eliot's play for the Mercury Theatre after its premiere at Canterbury Cathedral, travelled to Barcelona to supervise some of the rehearsals (Picó, 1949, pp. 9, 11-12). Ten years later, Robert Speaight, famous for being the first actor to perform the role of Beckett, gave recitals of fragments from Murder in the Cathedral at the Institut del Teatre and the Madrid Ateneo. One year before Speaight's visit, in 1957, students from the Madrid School of Civil Engineering had

\footnotetext{
8 "Hay un río profundo que transcurre por dentro de ellas y que apenas se oye aunque está".

9 “[E]l lenguaje poético del autor se sirve de amplios períodos íntimamente rítmicos, misteriosamente encadenados, que van envolviendo al auditorio en su mística fascinación”.

10 “[A]dmirables versos blancos"; "un aire de procesión litúrgica con ritmo de salmo".
} 
staged Asesinato en la Catedral at the Teatro de la Comedia. Other (semi)amateur or student productions took place in the 1960s in Madrid and Barcelona.

The report of a censor in the final years of Francoism warned against the danger to misrepresent Beckett's staunchness as arrogance or vanity, but raised no major objection ([Censorship report by "Padre Gea"] 1970). In general, Murder in the Cathedral was positively viewed as promoting Catholic values among popular audiences in the tradition of the mystery play, which a reputed author attempted to modernise. In the 1940s and 1950s, when The Family Reunion and The Cocktail Partyplays with a modern setting-were performed in Madrid and Barcelona, reviewers were more critical of their moral and theological implications, and sceptical that Spanish audiences could relate to these.

\section{The Scrutiny of Spanish National Catholicism}

In Eliot's The Family Reunion, Harry, Lord Monchensey, returns to Wishwood, his family home, tormented by a deranging sense of guilt. He confesses to his mother the Dowager and his relatives that he killed his wife, whom they all believed had committed suicide. Harry must atone for his sin and negate the family curse, about which he learns in the course of his stay. Expiation is urged by the Eumenides who haunt Harry, and propitiated by his visionary Aunt Agatha. At the end of the play, the Eumenides are no longer terrifying but "bright angels" whom Harry must follow_in Agatha's words_- “on a pilgrimage of expiation” (Eliot, 2004, pp. 339, 350).

Despite the ray of hope with which the play concludes, the reviewer of its earliest performance in Spain (by "Thule Teatro de Ensayo," in Barcelona in 1949) chose to focus on the existential agonies of Eliot's characters, associating them, in a moralising tone, with the absence of faith and familial support:

It is [...] a terrifyingly pessimistic play, with sombre characters. They face the tragedy of souls that resist an inevitably fatal destiny, unable to find either remedy or consolation - not even in the bosom of the family - because their weak foundations shake, lacking faith and spirituality, giving in to the mind's wild imaginings, continually fighting conscience, whose voice, as if crying out for redemption, draws us nearer to God. (De Cala, 1949, p. 6) ${ }^{11}$

The play's alleged obscurity, as well as the feeling of hopelessness that pervades it, make it incompatible - in the critic's view-with Spanish theatrical tastes, considered to reflect a supposed national character presented as self-contained and

\footnotetext{
11 "Mas es una obra de un pesimismo aterrador, sus personajes sombríos; la tragedia de sus almas, en pugna con el destino que las arrastra a la fatalidad, no halla remedio ni consuelo ni aún en el seno de la familia, porque sus cimientos carcomidos se tambalean carentes de fe, de espiritualidad, rindiéndose a las lucubraciones de la mente en continuo batallar con la conciencia, cuya voz, cual grito de redención, nos acerca a Dios".
} 
impervious to alien influence: "our southern temperament, which will not contain or assimilate anything contrary to its spirit" (De Cala, 1949, p. 6). ${ }^{12}$

When The Family Reunion was staged a few years later by Dido, an unenthusiastic critique also set into relief the protagonist's fatal destiny, overlooking the transformation experienced by Harry at Wishwood, which enables him to commit himself to redemption. Further, the sense of doom that weighs on the audience is attributed to "a certain uncatholic fatalism that has surrendered to the pointlessness of trying to modify the order of things" (Fernández Asís, 1956a, p. 13). ${ }^{13}$ Since the reviewer refers neither to Eliot's religious stance nor to the play's thematic foci as concomitant with it, we may assume that his impression is produced by two elements in The Family Reunion that are human-centred or pagan: its existentialism-although, as Palmer notes, it "does not deny Eliot's Christian orthodoxy" (1962, p. 175)—and its indebtedness to Greek tragedy - the play is based on Aeschylus' The Furies.

The use of the adjective "uncatholic," however, to define an aspect of a play by Eliot is puzzling. He was a devout Anglo-Catholic and his faith-not dissimilar to Roman Catholicism in aspects of practice_- "is the dominant element of his life and work" (Spurr, 2010, p. ix). The theme of adultery as presented by Eliot in The Cocktail Party raised objections among Spanish critics, both because of the dramatist's Anglo-Catholicism and the expectations of Spanish audiences, based on their dramatic tradition. In Eliot's first comedy, the London middle-class couple who host the cocktail party, Edward and Lavinia Chamberlayne, are going through a marital crisis. In the second scene, and in a rather understated way, we learn that one of its symptoms is Edward's affair with Celia, a young friend of the couple's. Celia speaks candidly to Edward:

You know I accepted the situation

Because a divorce would ruin your career;

And we thought that Lavinia would never want to leave you. (Eliot, 2004, p.

In turn, Peter, another young guest at the cocktail party, is attracted to Celia, which seems to be the reason why he has put an end to his relationship with Lavinia. In the second act, this is matter-of-factly revealed by Sir Henry-counsellor and spiritual "Guardian" who helps the Chamberlaynes overcome their crisis-as he reproaches Lavinia for her insincerity: "But you failed to mention that the cause of your distress / Was the defection of your lover [Peter]" (Eliot, 2004, p. 408).

Eventually, Edward and Lavinia's reconciliation will exemplify the "affirmative way" of "Christian marriage" as a reflection of divine love (Smith, 2014, p. 254). Reciprocal adultery is of little relevance when it can be overcome, in pursuit of a blessed state. When The Cocktail Party was performed in Madrid in 1952, a reviewer praised Eliot's achievement in "raising a most ordinary theme (adultery) to

\footnotetext{
12 "[N]uestra idiosincrasia meridional, receptáculo resistente a toda asimilación contraria a su espíritu".

13 "[C]ierto fatalismo no católico y resignado a la inutilidad de pretender modificar el orden de las cosas".
} 
a plane of moral and religious elevation" (T. M., 1952, p. 12). ${ }^{14}$ Other reviews-as had happened with The Family Reunion in 1949_failed to highlight final salvation; instead, they expressed concern over the moral disorientation that precedes it, of which adultery is an expression. In that sense, Eliot's non-judgemental presentation of the issue was found to be at odds with Spanish morals: "The coolness with which the protagonists receive the news of adultery is not quite compatible with our understanding of marital fidelity" (Marqueríe, 1952, p. 9). ${ }^{15}$

The author and critic Torrente Ballester also reviewed the María Guerrero production of The Cocktail Party, attributing its lukewarm reception to the neutrality with which the play presents the question of adultery. In accordance with the assumptions of Spanish National Catholicism, he argues that female adultery deserves a more severe social condemnation and draws attention to the essential difference between the dramatic situation of infidelity as treated by Eliot and by the Spanish Renaissance teatro del honor (Torrente Ballester, 1952, p. 12) — still a prevailing model in the mid twentieth century-where the convention is to make it the central conflict and the main characters are an adulterous woman and a man impelled to defend his honour.

Unlike other Spanish reviewers, Torrente Ballester accurately describes Eliot's religious stance as an Anglo-Catholic, but laments that The Cocktail Party treats adultery with "Christian vagueness" and "Anglo-Saxon poetic indeterminacy" rather than "categorical Catholic words" or "well-defined, precise symbols and words, following Latin conventions" (Torrente Ballester, 1952, p. 12). ${ }^{16}$ He feels certain that a Spanish audience would have found it easier to relate to a familiar Catholic pattern of confession, absolution and penitence: "We would have liked Doctor Reilly to tell the adulterous couple: 'Go and confess to a priest, receive sacramental absolution and start a new life' [...] In this way, signs would have been a lot more specific, allowing us to label the play 'Catholic'" (Torrente Ballester, 1952, p. 12). ${ }^{17}$ One could argue that the critic is missing the point, since beneath the literal plane of counselling in a modern urban context, Reilly also fulfils the role of confessor (Spurr, 2010, p. 143).

Other critics share Torrente Ballester's view that Eliot's play lacks the alleged exactness of Catholic dogma in dealing with adultery. As a therapist, Reilly treats Lavinia and Edward by means of discussion that leads to the couple's reconciliation and, more transcendently, their salvation. An audience supposedly comfortable with dogma is unlikely to appreciate this component of theological disquisition. Eliot's The Cocktail Party is

\footnotetext{
14 "[T]rasponer a un plano de elevación moral y religiosa un vulgarísimo tema de adulterio".

15 "No es para nuestro modo de entender la fidelidad matrimonial la tranquilidad con que reciben la noticia de adulterio los protagonistas".

16 "[V]aguedades cristianas", "poéticas indeterminaciones sajonas", "palabras católicas tajantes", "símbolos y palabras recortadas, precisas, a la manera latina".

17 "Nos hubiera gustado que el doctor Reilly dijera al matrimonio adúltero: 'Id y confesaos con un sacerdote, recibid la absolución sacramental y rehaced vuestra vida' [...] Por lo menos hubiéramos tenido datos mucho más concretos para calificar la obra de católica".
} 
intended for the English, European, even American character, but somewhat confusing for the Spaniard's traditional character, which has such a clear, ancestral and irreducible concept of Christian morals and cannot understand the reasoning-however serene and thorough — adopted by the author, who aims at justifying moral reactions in a conflict like adultery, without suppressing the cause (De Alcalá, 1952, p. 17). ${ }^{18}$

The intellectual José María Pemán—remembered today for his association with Francoism-expressed a similar opinion. He finds Eliot's play insightful but vague in its resolution because lacking in "the exact Latin aspect of dogma [...] the Roman clarity of that which is worthwhile" (1952, p. 19). ${ }^{19}$

Critics may find vagueness in Eliot's dramatization of his characters' progress to redemption. However, as a religious thinker, he often expressed "the characteristic Anglo-Catholic impatience with the Anglican reluctance to take a clear stand" on issues "which carried the Roman taint" (Spurr, 2010, pp. 141-142)—one of these was confession, which, as pointed out above, was proposed by a Spanish critic as an alternative remedy for Lavinia and Edward. In general, critical perception of moral lassitude in The Cocktail Party is hardly compatible with a nuanced description of its author's religious beliefs: “The Anglo-Catholicism to which he [Eliot] adhered was nothing if not dogmatic in its keenness to affirm its Catholic credentials in the non-ecumenical, absolutist climate of international, pre-conciliar Roman Catholicism-but also, as the coinage suggests, it was conscious of its Englishness" (Spurr, 2010, p. xi).

Eliot's conversion to Anglo-Catholicism in 1927 crucially coincided with his naturalisation as a British citizen. It is to this cultural determinant and to Eliot's intellectual approach to faith-despite his acceptance of dogma-that critics express subtle reservations, in a context of alliance between the Spanish Catholic Church and a dictatorial regime that cultural life could not escape. Eliot's religious outlook is critically marked as distinct from Spanish Catholicism, and the moral dimension of his modern plays seems difficult to relate with Spanish cultural and dramatic tradition.

\section{Sung, Dramatised and Read Verse}

As explained above, from the late 1950s, the emergence of a generation of "angry young men" and their "kitchen-sink drama" relegated Eliot's plays. The echoes of this effect in Spain meant that practically only Murder in the Cathedral continued to be staged, and that very occasionally. The contemporary success of Eliot's play led to its adaptation to other media: a British film directed by George Hoellering,

\footnotetext{
18 "[P]ensado para el carácter inglés y europeo y hasta americano, pero algo confuso para el tradicional carácter español, que tiene un concepto tan claro, tan ancestral y tan irreductible de la moral cristiana y no comprende los razonamientos, por serenos y meticulosos que aduce el autor, para justificar reacciones morales en conflictos de adulterio, sin eliminar la causa".

19 "[E]l perfil exacto y latino del dogma [...] la claridad romana de algo que valiera la pena".
} 
released in 1951 but not shown in Spain, and an opera by the Italian composer Ildebrando Pizzetti.

The first production of Assassinio nella Catedrale, after its premiere at the Teatro alla Scala (Milan) in March 1958, was at the Teatre del Liceu in Barcelona, in November of the same year. Pizzeti had composed the music and written the libretto, drawing on the Italian translation by Alberto Castelli and remaining faithful to the original plot. If, as we saw, many Spanish critiques of Eliot's plays drew attention to their difficult language, a reviewer of the first production of Assassinio nella Catedrale in Spain considered it challenging, because of its density and originality, for those accustomed to nineteenth-century opera (Vigil, 1958, p. 6). It was, however, generally well received and the Liceu would programme it again in 1978.

Also paired with music but popularly oriented, Eliot's verse would return to the Spanish stage as the musical Cats, performed at the Teatro Coliseum in Madrid for two seasons (2003-2005), at a time when the city was aspiring to become the "Spanish Broadway" (Mateo, 2008, pp. 326-27). Drawing on Eliot's Old Possum's Book of Practical Cats (1939)—which playfully portrays a number of singular personified cats-and other published and unpublished poems, Andrew Lloyd Webber and Trevor Nunn created a faintly narrative musical that revolved around a recognisably Eliotic motif: rebirth into a new life. For the Madrid production of this worldwide success, lyrics were translated by Mariano Detry. These were praised by critics, as well as the most ground-breaking aspects of the original production, such as Gillian Lynne's choreography. The newspaper $A B C$ accompanied its review of the musical with an article on Practical Cats and its significance within Eliot's production: “it is essential, in order to appreciate Eliot's creative scope thoroughly and fully, since it confers a richer and deeply human-even touching-dimension to the impressive poet of The Waste Land and Four Quartets" (García Garzón, 2003, p. 58). ${ }^{20}$

Apart from three of the canonical plays and the two intermedial musical adaptations commented on (drama to opera, poetry to musical theatre), Eliot's verse has also taken to the stage in Spain in less conventional forms, mostly as performed poetry. In 1988, students of the Madrid Real Escuela Superior de Arte Dramático (RESAD) presented Una partida de ajedrez, an artist's approach to the dramatic elements of the second part of The Waste Land, "A Game of Chess," directed by Chema Castelló. It was structured into scenes: a narrator opening and closing the sequence, a dialogue between the "neurotic woman" and her aloof lover, a woman chattering about Lil's demobbed husband's return. The aesthetics and atmosphere were inspired by Alain Resnais's stylised Last Year at Marienbad (1961) and the music of Olivier Messiaen. ${ }^{21}$

Another production inspired by the dramatic potential of Eliot's great poem was programmed in Madrid as part of the 2010 Festival de Otoño: the Teatro Español offered three performances of Deborah Warner's The Waste Land, with Fiona Shaw

\footnotetext{
20 “[E]s imprescindible para dibujar cabal y completo el perfil creativo de Eliot, pues otorga una dimensión más rica, entrañable si se quiere y profundamente humana al poeta impresionante de La tierra baldía o Cuatro cuartetos".

21 I am indebted to Castelló for details of this production.
} 
as sole actress and a minimalist mise-en-scène, in English and with Spanish surtitles. Interviewed by El Cultural, Warner declared that she had found "new and exciting material for the theatre" in a poem that "foreshadows many contemporary dramatic texts" (Perales, 2010). ${ }^{22}$ Ironically, Warner's dramatization goes back to a poetic text published in 1922, bypassing Eliot's later, purely dramatic texts, and which were also written in a spirit of innovation and experimentation.

Warner's The Waste Land premiered in 1995 in Brussels, prefiguring a renewed interest in Modernism and Eliot from the early 2000s, which resulted in numerous academic initiatives and activities (Perloff, 2007, pp. 12-14). This Anglo-American trend seems to have had its echo in Spain, where several recitals and dramatizations were programmed during the following decade, from 2010 to 2016.

The Waste Land also became inspiring material for a unique stage production that brought Eliot into relation with one of the key Catalan poets of the twentieth century, Salvador Espriu. Francesc Cerro Ferran created and directed La pell eixorca (La terra del brau), which combined fragments from the two poets' landmark works, Eliot's The Waste Land and Espriu's La pell de brau (1960). The latter can be translated into English as "the bull's hide," and it refers to the image used by the Greek geographer Strabo to describe the shape of the Iberian Peninsula-a bull's hide spread from West to East; La terra eixorca, on the other hand, is the title of the standard translation of The Waste Land into Catalan, by Agustí Bartra-La pell eixorca (La terra del brau), therefore, conflates the two titles. Espriu's collection revolves around the difficult coexistence of the peoples of Iberia, lamenting the debacle of the Spanish Civil War; like Eliot's poem, it captured a post-war collective mood very effectively. Apart from this thematic convergence in hopelessness provoked by historical crises, Espriu and Eliot are comparable in other ways, as encyclopaedic, allusive, meditative and transcendent poets. ${ }^{23}$

This comparative dramatization incorporated video projections of wasteland settings and art images, such as Picasso's Guernica and Goya's print series The Disasters of War-two expressions, arguably, of Spain's tragic fate. In an attempt to reproduce the polyphony of Eliot's poem, the only actress (Txe Arana) played different roles, mainly Tiresias, interacting with the video projections and the figure of a bull that symbolised Spain and whose voice was that of the actor Jaume Comas. $\mathrm{La}$ pell eixorca (La terra del brau) premiered at the Perelada music and drama festival in 2012 and was staged in several Catalan towns in the following year, coinciding with the centenary of Espriu's birth.

A dramatic reading of Eliot's The Elder Statesman (L'honorable home d'estat) was programmed by the Teatre Nacional de Catalunya (TNC) in 2013, as a complement to one of the main productions of the season, Harold Pinter's No Man's Land (1975). The dossier prepared by the TNC identifies echoes of the Dantesque imagery of The Waste Land or the spiritual quest-frustrated in No Man's Landof Four Quartets (Albertí, 2013, pp. 9, 14, 12). It also touches on Pinter's interest in Eliot's pageant play The Rock, and connects Spooner's causing Hirst to recall

22 "[M]aterial nuevo y excitante para el teatro"; "se adelanta a muchos textos de teatro contemporáneo".

${ }^{23}$ For a full comparative study of both poets, see Llorens-Cubedo (2013). 
painful episodes of the past (in No Man's Land) with Federico Gomez's unexpected and tense visit to Lord Claverton, which eventually helps the latter to expiate his past sins in The Elder Statesman (Albertí, 2013, pp. 9, 10). ${ }^{24}$

Dramatic readings of plays such as The Elder Statesman, dramatizations of a timeless crisis poem (The Waste Land), intermedial transpositions to opera and the stage musical (Assassinio nella Catedrale, Cats) and occasional, popular performances of Murder in the Cathedral are the varied expressions of Eliot's presence on Spanish stages after the 1950s, when his verse drama-in Spain as in other countries-began to lose its appeal.

\section{The Poet's Triumph (Conclusion)}

The 1948 Nobel Prize for Literature established Eliot as a prophet of cultivated modernity among Spanish intellectuals, attracting them to his poetry and-to a lesser extent-his criticism and drama. Because of his conservatism and adherence to Catholicism, Eliot was not targeted by the omnipresent Francoist censorship, which never barred the production of his plays on political or religious groundsreviewers were in a position to consider nuances and hence be more critical.

In the late $1940 \mathrm{~s}$ and in the $1950 \mathrm{~s}$, characterised by post-war political and economic constraints, most of these productions were amateur or student performances (Murder in the Cathedral produced by the Barcelona Institut del Teatre in 1949, for example), or staged by chamber theatre companies like Thule or Dido, whose Reunión de familia (1956) was discussed above. Escobar and De la Ossa's Cocktail Party (1952) was an exception, as we have seen: it was programmed by a national theatre and intended for a general audience.

Even at this time, when the conditions for the reception of Eliot's plays seemed the best possible, Spanish critics were sceptical of their feasibility as theatrical products: the depth of Eliot's verse-one of the main strengths of his poetry-was perceived as a weakness in his drama, almost an anti-dramatic feature. Spanish audiences were declared to be unreceptive to drama in which conceptually rich dialogue prevailed. Eliot was the master of profound verse who also wrote drama, rather than a pure dramatist.

According to reviewers, differences in religious outlook also contributed to the cold reception of The Family Reunion and The Cocktail Party: the fatalism of tragedy in the former was objected to as contrary to the theological virtue of hope; in the latter, the presentation of adultery as a symptom of spiritual disorientation rather than a breach of patriarchal honour was considered an oddity, when compared to Spanish dramatic tradition. In the context of the politically and socially powerful National Catholicism, certain critics (Torrente Ballester, Pemán) were puzzled by Eliot's deliberative approach to adultery, less suitable than the resolutely condemnatory attitude typical of-so they claimed-Roman Catholicism. Indeed, a prejudiced

\footnotetext{
24 The TNC dossier includes a long excerpt (pp. 9-10) from Ronald Knowles's "Harold Pinter and T. S. Eliot" (The Pinter Review: Collected Essays 1999-2000).
} 
view of Anglo-Catholicism as alien and vaguely suspicious seems to underlie the most elaborate reviews of The Cocktail Party. Only reluctantly were Eliot's plays recognised as "Catholic."

After the 1950s, only Murder in the Cathedral seems to have stood the test of time: it has often been produced by (semi)amateur groups, on special occasions, in emblematic settings and as recently as 2016. Its operatic version by Pizzetti was also well received at the Liceu in Barcelona, where it was programmed in the late 1950s and late 1970s.

Following Eliot's absence from Spanish stages in the 1980s and 1990s, the new millennium brought success for Cats in Madrid, which contributed to paving the way for frequent productions of musicals in the city. This example of the popularisation of Eliot's work contrasts with later dramatic projects, produced or performed in Spain in the 2010s: Warner's The Waste Land, Cerro Ferran's La pell eixorca or L'honorable home d'estat at the TNC. These approach Eliot as the influential and oracular giant of poetry whose verse has an appealing dramatic potential-a relative triumph for the great poet who dreamed of becoming a successful man of the theatre.

\section{Authors' contribution Not applicable.}

Funding Open Access funding provided thanks to the CRUE-CSIC agreement with Springer Nature. The research resulting in this article relates to the project "T. S. Eliot's Drama from Spain: Translation, Critical Study, Performance (TEATREL-SP)," funded by the Spanish Ministerio de Ciencia, Innovación y Universidades and by the European Regional Development Fund (PGC2018-097143-A-I00).

Availability of data and material Not applicable.

Code availability Not applicable.

\section{Declarations}

Conflict of interest The author declares no conflicts of interest.

Ethical approval Not applicable.

Consent to participate Not applicable.

Consent for publication Not applicable.

Open Access This article is licensed under a Creative Commons Attribution 4.0 International License, which permits use, sharing, adaptation, distribution and reproduction in any medium or format, as long as you give appropriate credit to the original author(s) and the source, provide a link to the Creative Commons licence, and indicate if changes were made. The images or other third party material in this article are included in the article's Creative Commons licence, unless indicated otherwise in a credit line to the material. If material is not included in the article's Creative Commons licence and your intended use is not permitted by statutory regulation or exceeds the permitted use, you will need to obtain permission directly from the copyright holder. To view a copy of this licence, visit http://creativecommons.org/licen ses/by/4.0/. 


\section{References}

Ackroyd, P. (1984). T. S. Eliot. A life. Simon \& Schuster.

Albertí, X., dir. (2013). Terra de ningú, by Harold Pinter [Dossier]. Teatre Nacional de Catalunya.

Ascunce Arrieta, J. A. (2015). Sociología cultural del franquismo (1936-1975). La cultura del nacionalcatolicismo. Biblioteca Nueva.

Bloin, B. (2007). Dido Pequño Teatro de Madrid i la seva directora Josefina Sánchez Pedreño. Assaig De Teatre, 59, 107-116.

Calvo, L. (1951). Eliot en Madrid. ABC, 9 May, 3-4.

[Censorship report by "Padre Gea"]. 1970. Application for performance of Murder in the Cathedral in Barcelona (file 101-70), Archivo General de la Administración, Alcalá de Henares, Madrid.

Centro de Documentación de las Artes Escénicas y de la Música (INAEM). Teatro y circo. http://teatro. es/. Accessed 27 July 2021.

Chinitz, D. (2003). T. S. Eliot and the cultural divide. University of Chicago Press.

Conde, C. (1956). Antecrítica de Reunión de familia. Ya, 19 June, 8.

Corifeo. (1952). Autocríticas de autor e intérpretes: Cocktail Party. Ya, 28 February, 6.

De Alcalá, J. (1952). Un Premio Nobel entre dos revistas, curioso sándwich de la semana. Noticiero universal, 3 March, 17.

De Cala, M. (1949). En el Comedia. Estreno de Reunión de familia, por la Agrupación Thule, Teatro de Ensayo. Noticiero universal, 31 May, 6.

De Castro, C. (1952). María Guerrero: Estreno de Cock-tail party. Madrid, 29 February, 10.

Eliot, T. S. (2004). The complete poems and plays. Faber and Faber.

Eliot, T. S. (2018). Poetry and drama. In I. Javadi and R. Schuchard (Eds.), The complete prose of T. S. Eliot: The critical edition. Volume 7: A European society, 1947-1953 (pp. 589-610). Johns Hopkins University Press, Faber \& Faber.

Fernández Asís, V. 1956a. Dido: Reunión de familia, de T. S. Eliot. Pueblo, 20 June, 13.

Fernández Asís, V. 1956b. 7 días. Estafeta literaria, 23 June, 7.

Fundación Juan March (Madrid). Fondo de Teatro Español Contemporáneo. https://www.march.es/bibli otecas/biblioteca-teatro.aspx?1=1. Accessed 27 July 2021.

García Espina, G. (1952). Cocktail Party (María Guerrero). El Alcázar, 29 February, 2.

García Grazón, J. I. (2003). La zarigüeya y los gatos. ABC, 17 December, 58.

Gardner, H. (1985). The comedies of T. S. Eliot. In A. P. Hinchcliffe (Ed.), T. S. Eliot: Plays (pp. 42-60). Macmillan.

Haro Tecglen, E. (1950). Asesinato en la Catedral. Un auto sacramental del Premio Nobel Eliot representado en la Catedral de Burgos. Semana, 4 July, n. p.

Hormigón, J. A., ed. (2005). Directoras en la historia del teatro español (1550-2002). Volumen 3. Publicaciones de la Asociación de Directores de Escena de España.

INAEM - Centro de Documentación Teatral. (2017). Figuras: Luis Escobar Kirkpatrick. Documentary. Teatro.es. https://www.teatro.es/contenidos/figuras/luis-escobar/. Accessed 27 July 2021.

Institut del Teatre (Barcelona). Escena Digital (Museu de les Arts Escèniques). http://colleccions.cdmae. cat/. Accessed 27 Julio 2021.

Jenabe. (1956). Una buena velada del teatro Dido. Ya, 6 June, 6.

Laborda, A. (1952). Esta noche, en el María Guerrero, Cock-tail party. Informaciones, 29 February, 5.

Llorens-Cubedo, D. (2013). T. S. Eliot and Salvador Espriu. Converging poetic imaginations. Publicacions de la Universitat de València.

Marqueríe, A. (1952). Estreno de Cock-tail party, de Eliot, en el María Guerrero. Pueblo, 29 February, 9.

Marqueríe, A. (1956). Estreno de Reunión de familia, en 'Dido'. ABC, 20 June, 59.

Mateo, M. (2008). Anglo-American musicals in Spanish theatres. The Translator, 14(2), 319-342.

Morales, A. (1995). Introducción. In C. Conde, Nada más que Caín (pp. 9-18). Universidad de Murcia.

Palmer, R. E. (1962). Existentialism in T. S. Eliot's The family reunion. Modern Drama, 5(2), 174-186.

Pemán, J. M. (1952). Cocktail party. ABC, 13 April, 19.

Perales, L. (2010). Deborah Warner: "El deseo de contar con un material excitante para el teatro me llevó a Eliot”. El Cultural, 4 June, https://elcultural.com/Deborah-Warner-El-deseo-de-contar-conun-material-excitante-para-el-teatro-me-llevo-a-Eliot. Accessed 27 July 2021.

Perloff, M. (2007). The aura of modernism. In V. Patea and P. S. Derrick (Eds.), Modernism revisited. Transgressing boundaries and strategies of renewal in American poetry (pp. 11-34). Rodopi.

Picó Capdevila, R. (1949). Memoria del curso 1948-49. Instituto del Teatro de Barcelona. 
Prego, A. (1956). Crítica: Reunión de familia, de T. S. Eliot, por el Pequeño Teatro Dido. Informaciones, 21 June, 9.

Rodríguez Guerrero-Strachan, S. (2007). Multiple voices, single identity: T. S. Eliot's criticism and Spanish poetry. In E. Däumer and S. Bagchee (Eds.), The international reception of T. S. Eliot (pp. 141153). Continuum.

Sánchez Pedreño, J., dir. (1956, June 19). Reunión de familia, by T. S. Eliot [Programme]. Madrid: Instituto de Previsión.

Smith, C. H. (2014). Eliot's divine comedies: The cocktail party, The confidential clerk and The elder statesman. In D. E. Chinitz (Ed.), A companion to T. S. Eliot. (pp. 251-62). Wiley Blackwell.

Spurr, B. (2010). Anglo-Catholic in religion. T. S. Eliot and Christianity. Lutterworth Press.

TEATREL-SP. http://teatrel.linhd.uned.es/index.html. Accessed 27 July 2021.

T. M. (1952). María Guerrero: Estreno de Cock-tail party. Arriba, 29 February, 12.

Torrente Ballester, G. (1952). El estreno de Cocktail party. Correo literario, 15 March, 12.

Vigil. (1958). Asesinato en la catedral, de Pizzeti, en el Liceo. Ya, 23 November, 6.

\section{Appendix: Stage Performances of Eliot's Work in Spain}

1949 (May). Reunión de familia. Barcelona (Teatro Comedia). Prod. “Thule, Teatro de Ensayo.” Dir. Mariano Cruz Tovar, Ernesto Carratalá. Trans. Ernesto Carratalá.

1949 (June). Barcelona (Plaça del Rei). Asesinato en la Catedral. Prod. Institut del Teatre. Dir. Marta Grau.

1950 (July). Terrassa, Barcelona (Esglésies de Sant Pere). Asesinato en la Catedral. Dir. Artur Carbonell. Trans. Francesc de A. Carreres.

1950 (June). Burgos (Cathedral). Asesinato en la Catedral. Dir. José María Gavilán. Cast: Fernando Fernán Gómez, Manuel Dicenta (among others).

1952 (February). Madrid (Teatro Nacional María Guerrero). Cocktail Party. Dir. Luis Escobar, Huberto Pérez de la Ossa. Trans. José Méndez Herrera. Cast: Adolfo Marsillach, Carmen Seco, Mari Carmen Díaz de Mendoza, José María Rodero, Enrique Diosdado, Enrique Guitart, Blanca de Silos, Berta Riaza.

1955 (November). Barcelona (Teatro C.A.P.S.A). Cocktail Party. Prod. Teatro Español Universitario (TEU). Dir. Mario Cortés, Antonio Chic. Trans. José Méndez Herrera.

1956 (June). Madrid. Reunión de familia. Prod. "Pequeño Teatro Dido." Dir. Josefina SánchezPedreño, Trino Martínez Trives. Trans. Elisa Fernández-Cancela (Elizabeth Gate), Carmen Conde. Cast: Julia Delgado Caro, Josefina de la Torre, María Antonieta Escrivá, Carmen Lecquerica, Victorico Fuentes, Sergio Mendizábal, María Abelenda, Ramón Corroto, Bonifacio de la Fuente, Javier Loyola.

1957 (May). Madrid (Teatro de la Comedia). Asesinato en la Catedral. Prod. Madrid School of Civil Engineering. Dir. Tomás Torres.

1958 (October-November). Madrid (Ateneo) and Barcelona (Institut del Teatre). Readings from Murder in the Cathedral by Robert Speaight.

1958 (November). Barcelona (Teatre del Liceu). Assassinio nella Cattedrale (opera). Music and libretto: Ildebrando Pizzetti, based on Alberto Castelli's Italian translation.

1962 (November). Barcelona (Teatro Candilejas) and Madrid (Instituto Británico). Two Saints in Two Plays (based on Murder in the Cathedral and Robert Bolt's A Man for All Seasons). Organised by the British Council.

1963. Figueres, Girona (Església de Sant Pere). Asesinato en la Catedral. Prod. Institut del Teatre. Dir. Hermann Bonnin.

1964 (November). Madrid (Instituto Ramiro de Maeztu). Asesinato en la Catedral (Murder in the Cathedral). Student production. Dir. Carlos Cano, Salvador Salazar.

1965 (February). Barcelona (Centre Parroquial d'Horta). Assassinat a la Catedral. Prod. "Grup d'Estudis Teatrals del Centre Parroquial d'Horta." Dir. Francesc Espluga. Trans. Josep M. Urdeix.

1970 (April). Barcelona (Institut d'Estudis Nordamericans). Asesinato en la Catedral. Prod. "Teatro Independiente Gogo." Dir. Josep Maria Puyal. Trans. Francesc de A. Carreres.

1978 (January). Barcelona (Teatre del Liceu). Assassinio nella Cattedrale (opera). See 1958, above. 
1988. Madrid (Real Escuela Superior de Arte Dramático, RESAD). Una partida de ajedrez (based on The Waste Land). Prod. RESAD. Dir. Chema Castelló.

2003-2005. Madrid (Teatro Coliseum). Cats (musical). Prod. Cie España. Dir. Trevor Nunn, Chrissie Cartwright. Trans. Mariano Detry. Cast: Teresa Cora, Helen de Quiroga, Guadalupe Lancho, Jack Rebaldi, Pedro Ruy-Blas, Víctor Ullate Roche, Enrique Sequero (among others).

2004. Madrid (Ateneo). Cocktail Party. Prod. "Teatroz."

2010 (June). Madrid (Teatro Español). The Waste Land. Dir. Deborah Warner. Perf. Fiona Shaw.

2010 (March-April). Girona (La Planeta). Assassinat a la Catedral (dramatised reading). Prod. Proscenium. Dir. Joan Ribas.

2012 (May). Barcelona (Cathedral, Pla de la Seu). Assassinat a la Catedral. Prod. Centre Moral i Cultural de Poblenou. Dir. Noèlia Ortega, Lourdes Mas, Mercè Guilló. Trans. Josep M. Urdeix.

2013 (July). Figueres, Girona (Teatre El Jardí). La pell eixorca (La terra del brau) (dramatization of poems by Eliot and Salvador Espriu). Prod. and dir. Francesc Cerro-Ferran. Cast: Txe Arana, Jaume Comas. Toured other Catalan towns.

2013 (October). Barcelona (Teatre Nacional de Catalunya). L'honorable home d'estat (dramatised reading). Dir. Mònica Bofill. Cast: Marta Angelat, Dafnis Balduf, Imma Colomer, Pep Cruz, Mingo Ràfols, Santi Ricart, Aina Sánchez. Trans. Albert Arribas.

2015 (March). Reus, Tarragona (Teatre Fortuny). Història d'un assassinat a la Catedral (based on Murder in the Cathedral). Dramatised reading. Dir. Francesc Cerro-Ferran. Cast: Txe Arana, Joan Carreras, Lluís Marco.

2016 (May). Cordova (Mosque Cathedral). La sangre de los mártires (based on Murder in the Cathedral. Prod. "Compañía de Teatro Clásico de Córdoba - Teatro Par." Adapt. and dir. Antonio Barros.

Publisher's Note Springer Nature remains neutral with regard to jurisdictional claims in published maps and institutional affiliations. 